\title{
Impact of Leadership Styles on Employee Engagement Pre and During Covid- 19 in the IT Industry - An Exploratory Study
}

\author{
V D Krishnaveni ${ }^{1}$, Dharshini $\mathrm{J}^{2}$, Karpagaavalli $\mathrm{M}^{3}$ \\ \{krishnaveni.damodaran@gmail.com ${ }^{1}$,dharshujeyaraj@gmail.com ${ }^{2}$, karpagavalli1998@gmail.com ${ }^{3}$ \} \\ PSG Institute of Management ${ }^{1,2,3}$
}

\begin{abstract}
The Covid pandemic has ushered in many business-level changes, especially in the IT sector where remote working has become the norm. Leaders have a larger responsibility to mould employees and improve performance. Employee engagement will be key to achieving higher productivity during such times. This study aims at evaluating how the Covid pandemic has altered leadership styles and employee engagement in the IT Industry in southern India. An online survey instrument based on the Utrecht Work Engagement Scale was used to record and measure employee engagement levels. Factors of transformational and transactional leadership were also measured. Around 100 respondents were surveyed about their work experiences before and during COVID-19. Data analysis revealed that transformational leadership corresponded to higher employee engagement levels among IT employees.
\end{abstract}

Keywords: COVID pandemic, IT sector, Transactional leadership, Transformational leadership, Work from home, Employee engagement.

\section{Introduction}

COVID- 19 pandemic has created a big shift in the working mode across most sectors of business. As the pandemic spread uncontrollably, the IT sector shifted their working mode to "Work from home." This work-from-home has enabled managers and employees to work together even when they were geographically apart. Implementation of Work-From-Home has helped retain the business of the IT sector. Nevertheless, the new normal has brought difficulties for managers in coordinating with employees and maintaining the same level of engagement. It is important to have engaged employees in the company to keep it running successfully. When engaged employees turn into disengaged employees, it either forces the company to remove them or they leave the company themselves causing a loss for the company.

Leaders play a predominant role in the engagement level of the employees. Different styles of leadership have different impacts on employees. Instead of merely coping with the pandemic, managers and supervisors have got the additional responsibility of keeping their teams running with the same engagement levels as before the pandemic. 
COVID- 19 has had a huge impact on the business world and the economy. Organizations are working hard to mobilize and stabilize their business and return to pre-COVID work and efficiency levels. As the COVID- 19 pandemic kept evolving, there was a serious need for organizations to rethink and reconFig their processes for the new normal. Managers and supervisors were facing issues in analyzing the areas in which they needed to concentrate.

Given that around 4 million employees are directly employed in the IT industry in southern India, this study is especially important at this time as it evaluates the suitability of different leadership styles on employee engagement.

This study was restricted to IT professionals in southern India who have shifted to the Work-From-Home mode of operation during the COVID- 19 pandemic. This research focuses on the comparison between pre-Covid and during-Covid leadership styles and their impacts on employee engagement in the IT sector in southern India.

\section{Literature review}

The process of leadership is one through which a leader holds an influencing power over the thoughts, behaviours, and attitudes of the employees (Ramadevi\&Narayanamma, 2016; Zahid \&Özyapar, 2017) and it plays an important role in the organization in driving growth and success. Managers or supervisors are largely responsible for increasing the level of employee engagement at the workplace.

Leadership is about having an impact on the subordinates and their engagement level. A recent study concluded that a leader is a person who can influence the behaviour of others without having to depend on the threat of force or other forms (YuponoBagyo, 2014). It is significant that leaders create an environment of learning and development for the employees and also for the working organization (Gentry, 2012). The leaders' support gives an optimistic attitude to employees in working places (Parimalam and Mahadevan, 2012).

Leadership styles are classifications of how a person behaves while leading a group of individuals. They are influenced by behaviours like being authoritarian, participative, or delegative. There are various ways to lead people or groups of people but primarily leadership is found to be transactional or transformational.

\section{Transformational and Transactional Leadership}

Transactional leaders mainly focus on the process and controls, following a strict management structure. This style is concerned with how to get things done by individuals. Focusing on the goals, such leaders are mostly reactive in nature and use rewards as a key for motivating their subordinates. The transactional leader mainly looks at established goals by making a clear view of task requirements, whereas a transformational leader moves beyond the task requirements (Bezuidenhout \& Schultz, 2013). Such leaders focus on being an inspiration to others and possess a high level of coordinating and communicating skills. Focusing on the vision, they are proactive in nature and use charisma and enthusiasm for motivating people. Transformational leadership is attributed to that approach of leadership that leads to alterations in the views of followers (Gözükara\& Faruk, 2015). The behaviour of transformational leaders is positively correlated with employee engagement and its various dimensions. Transformational leadership style includes characteristics like inspirational 
motivation along with influence, the ability to stimulate intellectually and consideration for the individual. Such leaders have the potential to bring out the best in their employees by inculcating confidence in them (Popli\&Razvi, 2016). The transformational leaders are more self-confident in bringing an engaging culture into an organization (Batista-Taran, 2013).

\section{Employee Engagement}

Employee engagement is indicative of how employees relate to their workplace. It is the level to which the employees in the organization feel passionate about their job, committed towards the organization, and influences the effort they put in at the organization. It is an important factor for retaining employees. It is an emotional connection which a person carries while working in the organization.

Employee engagement is the key factor that contributes to the efficiency of the organization, achievement, and success (Zahid \&Özyapar, 2017). Work engagement is a term that broadly refers to the significance of a worker's work and the magnitude of concentration that is being invested (Gözükara\&Şimsek, 2015). There is a need for a healthy, committed, and motivated workforce in an organization to perform efficiently and be termed as engaged employees. Organizations with high levels of impact of leadership on the work engagement of employees entail positive organizational outcomes (Rama Devi \& Lakshmi Narayanamma, 2016). Employee engagement at work has a fundamental association with the effectiveness of leadership (Asiedu \& Darko, 2017; Othman, 2017; Zahid \&Özyapar, 2017). Leadership style has an important impact on employee engagement; therefore, leaders must have a clear understanding of the concept (Gentry, 2012).

After sufficient literature review and discussion with experts, various constructs were found to be significant in this study. Vigour defines the willingness and physical energy of an employee. The high level of energy makes employees invest in work more. Dedication defines the enthusiasm level of employees. Dedicated employees contribute to the job more, because they feel that they're significant to the job. Absorption defines the workflow of employees. The workflow here describes the positive mentality in which employees work. The variables and their relationships are depicted in the theoretical framework below:

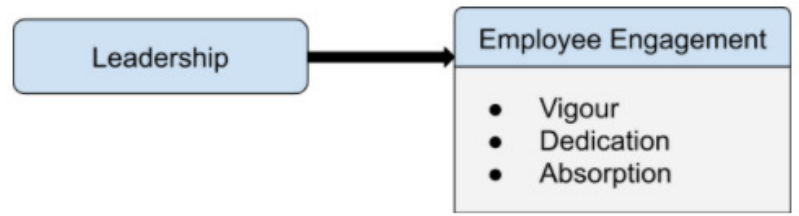

Fig 2.1 Framework of the research

\section{Research Methodology}

This study was quantitative in nature and empirical data was collected using online questionnaires from various employees from IT companies in southern India. As this was an exploratory study, convenience sampling was used. The number of completed and usable responses was 102. Data was collected from IT employees from various organizations and 
various designations. The respondents were predominantly from southern India working in MNCs across the country. These employees were working with the organization before and during COVID- 19 pandemic situation, i.e. they have worked both in the physical environment and also the remote working environment. The reliability of the questionnaire was tested initially with 20 responses from the questionnaire and Cronbach's alpha value was found to be 0.92 which satisfies questionnaire validity.

Utrecht Work Engagement Scale was used to collect and measure employee engagement with questions centered on three main factors, namely vigour, dedication, and absorption. A multilevel Leadership Questionnaire was used to formulate the leadership questions.

The collected data was analysed to understand employee engagement levels and also to identify any associations between the different variables in the framework. Paired samples Ttest was performed to find the changes, if any, before and during COVID- 19 pandemic situation. A test of correlation was performed to understand the relation between the leadership styles of the supervisors and the engagement level of the employees for both before and during COVID- 19. Regression analysis was made to find the impact of each leadership style of the direct supervisor on the overall engagement level of the employee for both the conditions of the COVID- 19 pandemic.

\section{Analysis}

Frequency analysis was conducted for the demographic data of the respondents. Through the results, it was understood that the number of men in the sample (i.e 67.6\%) was higher than women (i.e 32.4\%). Also, only very few people above 50 years of age (i.e $1 \%$ ) were part of the sample. Most of the respondents have work experience of 2 to 4 years (i.e. $42.2 \%$ ) and the next $27.5 \%$ have less than 2 years of work experience. Most of the people were working less than 48 hours a week (i.e $44.1 \%$ ).

\section{$\underline{4}$ Employee engagement level before and during COVID-19}

H1. There is no significant difference in employee engagement levels of the employee before COVID- 19 and during COVID- 19.

Table 4.1: Engagement level of employees before and during COVID- 19.

\begin{tabular}{|l|c|c|c|c|c|c|}
\hline & Mean & $\mathbf{N}$ & $\begin{array}{l}\text { Standard } \\
\text { Deviation }\end{array}$ & $\begin{array}{c}\text { Standard } \\
\text { Error } \\
\text { Mean }\end{array}$ & $\mathbf{t}$ & $\begin{array}{c}\text { Sig. (2- } \\
\text { tailed) }\end{array}$ \\
\hline $\begin{array}{l}\text { Engagement level before } \\
\text { COVID - 19 }\end{array}$ & 39.39 & 102 & 8.737 & 0.865 & & \\
\hline $\begin{array}{l}\text { Engagement Level during } \\
\text { COVID- 19 }\end{array}$ & 37.58 & 102 & 9.107 & 0.902 & & \\
\hline $\begin{array}{l}\text { Engagement level before and } \\
\text { during COVID - 19 }\end{array}$ & 1.814 & & 5.837 & 0.578 & 3.138 & 0.002 \\
\hline
\end{tabular}


The paired sample T-test shows the difference in the level of employee engagement before-COVID and during COVID. There is a mean difference of 1.814 between the engagement level of employees before and during COVID. As the probability-value is less than 0.05 (i.e., $0.002<.05$ ), it can be concluded that there is a statistically significant difference between the two-variable scores (Before COVID and During COVID). Resulting in the hypothesis not being supported. The reason for the decrease in the engagement level of employees during COVID could be that their mode of working has changed to virtual mode. Before COVID, they used to go to the office and they were able to meet their colleagues and work along with them. But during COVID, they were working alone and their engagement has reduced.

\subsection{Transformational leadership style of supervisors before and during COVID- 19.}

H2. There is no significant difference in the Transformational Leadership level in supervisors before COVID- 19 and during COVID- 19.

Table 4.2: Transformational leadership style of supervisors before and during COVID19.

\begin{tabular}{|l|c|c|c|c|c|c|}
\hline & Mean & N & $\begin{array}{c}\text { Standard } \\
\text { Deviation }\end{array}$ & $\begin{array}{c}\text { Standard } \\
\text { Error } \\
\text { Mean }\end{array}$ & t & $\begin{array}{c}\text { Sig. (2- } \\
\text { tailed) }\end{array}$ \\
\hline $\begin{array}{l}\text { Transformational leadership } \\
\text { level before COVID - 19 }\end{array}$ & 23.78 & 102 & 6.36 & 0.63 & & \\
\hline $\begin{array}{l}\text { Transformational Leadership } \\
\text { Level during COVID- 19 }\end{array}$ & 23.30 & 102 & 6.185 & 0.612 & & \\
\hline $\begin{array}{l}\text { Transformational leadership } \\
\text { level before and during COVID } \\
-19\end{array}$ & 0.48 & & 3.296 & 0.326 & 1.472 & 0.144 \\
\hline
\end{tabular}

The paired sample T-test shows the difference in transformational leadership beforeCOVID and during COVID. As there is a mean difference of 0.480 between the transformational leadership level of employees before and during COVID and the probabilityvalue is greater than 0.05 (i.e., $0.144<.05$ ), it can be concluded that there is no significant difference between the two-variable scores (Before COVID and During COVID). So, the hypothesis is supported. Usually, transformational leaders are adaptive and understanding. During COVID also, they understood the situation and maintained the same style of leadership with their employees.

4. 3 Transactional leadership style of supervisors before and during COVID- 19.

H3. There is no significant difference in the Transactional Leadership level in supervisors before COVID- 19 and during COVID- 19.

Table 4.3: Transactional leadership style of supervisors before and during COVID- 19.

\begin{tabular}{|l|c|c|c|c|c|c|}
\hline & Mean & $\mathbf{N}$ & $\begin{array}{c}\text { StandardDevi } \\
\text { ation }\end{array}$ & $\begin{array}{c}\text { StandardEr } \\
\text { ror Mean }\end{array}$ & $\mathbf{t}$ & $\begin{array}{c}\text { Sig. (2- } \\
\text { tailed) }\end{array}$ \\
\hline Transactional leadership level & 22.35 & 102 & 5.116 & 0.507 & & \\
\hline
\end{tabular}




\begin{tabular}{|l|l|l|l|l|l|l|}
\hline before COVID - 19 & & & & & & \\
\hline $\begin{array}{l}\text { Transactional leadership Level } \\
\text { during COVID- 19 }\end{array}$ & 21.94 & 102 & 4.903 & 0.485 & & \\
\hline $\begin{array}{l}\text { Transactional leadership level } \\
\text { before and during COVID - 19 }\end{array}$ & 0.412 & & 2.805 & 0.278 & 1.483 & 0.141 \\
\hline
\end{tabular}

From the results of the paired sample T-test, it can be concluded that there is no significant difference between the two-variable scores (Before COVID and During COVID). So, the hypothesis is not supported. Even though employees and supervisors are working remotely in diverse workplaces, feedback is given to them whenever required. Because of this, employees feel that there is not much difference in transactional leaders.

\subsection{Transformational Leadership With Employee Engagement:}

H4. There is no significant association between employee engagement and the transformational leadership of the supervisor before and during Covid-19.

A Pearson correlation analysis between the transformational leadership of supervisor and employee's engagement level before COVID- 19 was 0.628 as shown in table 4.4 which was greater than that of the Pearson correlation between the transformational leadership of supervisor and employee's engagement level during COVID- 19 which was found to be 0.589 as shown in table 4.5. Hence it is found that the transformational leadership of supervisor and employee's engagement level with work is positively correlated before and during COVID- 19 pandemic. Thus, the above hypothesis (H4) is not supported. But the impact is comparatively higher before the COVID-19 situation where the mode of working is offline and employees were in the workplace environment with scheduled timing of work. But during COVID- 19 the employees are working from home with flexible timings.

\section{$\underline{\text { 4.4.1 Employee Engagement \& Transformational Leadership before COVID- } 19}$}

Table 4.4: Transformational leadership style of supervisors and Employee engagement before COVID- 19.

\begin{tabular}{|l|l|c|c|}
\hline & & $\begin{array}{c}\text { Employee Engagement } \\
\text { Before COVID- 19 }\end{array}$ & $\begin{array}{c}\text { Transformational } \\
\text { Leadership Before COVID- } \\
\mathbf{1 9}\end{array}$ \\
\hline $\begin{array}{l}\text { Employee Engagement Before } \\
\text { COVID- 19 }\end{array}$ & Pearson Correlation & 1 & $.628^{* *}$ \\
\cline { 2 - 4 } & $\begin{array}{l}\text { Significance (2- } \\
\text { tailed) }\end{array}$ & 102 & $<.001$ \\
\cline { 2 - 4 } & $\mathrm{N}$ & 102 \\
\hline
\end{tabular}

\subsubsection{Employee Engagement \& Transformational Leadership during COVID- 19}

Table 4.5: Transformational leadership style of supervisors and Employee engagement during COVID- 19. 


\begin{tabular}{|l|l|l|c|}
\hline & & $\begin{array}{l}\text { Employee Engagement } \\
\text { during COVID- 19 }\end{array}$ & $\begin{array}{l}\text { Transformational } \\
\text { Leadership during } \\
\text { COVID- 19 }\end{array}$ \\
\hline $\begin{array}{l}\text { Employee Engagement } \\
\text { during COVID- 19 }\end{array}$ & $\begin{array}{l}\text { Pearson } \\
\text { Correlation }\end{array}$ & 1 & $.589^{* * *}$ \\
\cline { 2 - 4 } & $\begin{array}{l}\text { Significance (2- } \\
\text { tailed) }\end{array}$ & & $<.001$ \\
\cline { 2 - 4 } & $\mathrm{N}$ & 102 & 102 \\
\hline
\end{tabular}

\subsection{Transactional Leadership and Employee Engagement:}

H5. There is no significant association between Employee engagement and transactional leadership of the supervisor.

The Pearson correlation between the transactional leadership of supervisor and employee's engagement level before COVID- 19 was 0.610 as shown in table 4.6 which was greater than that of the Pearson correlation between the transactional leadership of supervisor and employee's engagement level during COVID- 19 which was found to be 0.552 as shown in table 4.7. Hence it was found that the transactional leadership of supervisor and employee's engagement level with work is positively correlated before and during COVID- 19 pandemic. But, the impact was comparatively higher before the COVID- 19 situation where the mode of working was offline. When working in a workplace environment, employees get support from their supervisors when things go wrong and feedback is given immediately, but during remote working, at times of problems, there is difficulty in reaching the supervisor directly.

\subsubsection{Employee Engagement \& Transactional Leadership before COVID- 19}

Table 4.6: Transformational leadership style of supervisors and Employee engagement before COVID- 19.

\begin{tabular}{|l|l|c|c|}
\hline & & $\begin{array}{c}\text { Employee Engagement } \\
\text { Before COVID- 19 }\end{array}$ & $\begin{array}{c}\text { Transactional Leadership } \\
\text { Before COVID- 19 }\end{array}$ \\
\hline $\begin{array}{l}\text { Employee Engagement } \\
\text { Before COVID- 19 }\end{array}$ & $\begin{array}{l}\text { Pearson } \\
\text { Correlation }\end{array}$ & 1 & $.610^{* * *}$ \\
\cline { 2 - 4 } & $\begin{array}{l}\text { Significance (2- } \\
\text { tailed) }\end{array}$ & & $<.001$ \\
\cline { 2 - 4 } & $\mathrm{N}$ & 102 & 102 \\
\hline
\end{tabular}

4.5.2 Employee Engagement \& Transactional Leadership during COVID- 19

Table 4.7: Transactional leadership style of supervisors and Employee engagement during COVID- 19.

\begin{tabular}{|l|l|c|c|}
\hline & \multicolumn{1}{|c|}{$\begin{array}{c}\text { Employee } \\
\text { Engagement } \\
\text { during COVID- 19 }\end{array}$} & $\begin{array}{c}\text { Transactional } \\
\text { Leadership during } \\
\text { COVID- 19 }\end{array}$ \\
\hline Employee Engagement & Pearson & 1 & $.552^{* * \%}$ \\
\hline
\end{tabular}




\begin{tabular}{|l|l|c|c|}
\hline during COVID- 19 & Correlation & & \\
\cline { 2 - 4 } & $\begin{array}{l}\text { Significance (2- } \\
\text { tailed) }\end{array}$ & & $<.001$ \\
\cline { 2 - 4 } & $\mathrm{N}$ & 102 & 102 \\
\hline
\end{tabular}

There is a positive correlation between both the leadership style and employee engagement in all the situations, but transformational leadership's impact on employee engagement before COVID- 19 is higher among all the situations.

4.6.1 Employee engagement, Transactional and Transformational leadership before COVID - 19

Table 4.8: Regression analysis on Employee engagement, Transformational and Transactional leadership before COVID - 19.

\begin{tabular}{|l|l|l|l|l|l|}
\hline & \multicolumn{2}{|c|}{$\begin{array}{l}\text { Unstandardized Coefficients } \\
\text { Model }\end{array}$} & $\begin{array}{l}\text { Standardized } \\
\text { Coefficients }\end{array}$ & & \\
\hline & B & Standard Error & Beta & t & Sig. \\
\hline $\begin{array}{l}\text { (Constant) } \\
\begin{array}{l}\text { Transformational leadership } \\
\text { score before COVID- 19 }\end{array}\end{array}$ & 0.534 & 0.166 & & 5.013 & 0 \\
\hline $\begin{array}{l}\text { Transactional leadership score } \\
\text { before COVID- 19 }\end{array}$ & 0.524 & 0.207 & 0.389 & 3.208 & 0.002 \\
\hline
\end{tabular}

*Dependent variable: Employee engagement before COVID- 19

Regression analysis Transactional score and Transformational score $(\beta=.389$ and 0.307 , $\mathrm{p}=0.001<0.05)$ showed that they both had an impact on employee engagement of employees during COVID- 19. The t-test finds that both intercept and variable are highly significant $(\mathrm{p}<$ $0.001)$ leading to the equation below:

Employee Engagement before COVID- $19=14.981+(0.534 *$ Transformational leadership score before COVID- 19$)+(0.524 *$ Transactional leadership score before COVID19)

4.6.2 Employee engagement, Transactional and transformational leadership during COVID - 19

Table 4.9:Regression analysis on Employee engagement, Transformational and Transactional leadership during COVID - 19

\begin{tabular}{|c|c|c|c|c|c|}
\hline \multirow[b]{2}{*}{ Model } & \multicolumn{2}{|c|}{$\begin{array}{l}\text { Unstandardized } \\
\text { Coefficients }\end{array}$} & \multirow{2}{*}{$\begin{array}{l}\text { Standardized } \\
\text { Coefficients } \\
\text { Beta } \\
\end{array}$} & \multirow[b]{2}{*}{$\mathbf{T}$} & \multirow[b]{2}{*}{ Sig. } \\
\hline & B & Standard Error & & & \\
\hline (Constant) & 14.302 & 3.35 & & 4.27 & 0 \\
\hline
\end{tabular}




\begin{tabular}{|l|l|l|l|l|l|}
\hline $\begin{array}{l}\text { Transformational leadership } \\
\text { score during COVID- 19 }\end{array}$ & 0.601 & 0.195 & 0.408 & 7.698 & $<.001$ \\
\hline $\begin{array}{l}\text { Transactional leadership } \\
\text { score during COVID- 19 }\end{array}$ & 0.422 & 0.246 & 0.227 & 1.718 & 0.089 \\
\hline
\end{tabular}

*Dependent variable: Employee engagement during COVID- 19

Table 4.9 explains the significance of the impact of transformational leadership and transactional on employee engagement level during COVID- 19. Transformational score $(\beta=$ .408 and $0.227, \mathrm{p}=0.001<0.05$ ) has a higher impact on employee engagement of employees during COVID- 19 unlike the transactional leadership score. The t-test finds that both intercept and variable are highly significant $(\mathrm{p}<0.001)$.

Employee engagement during COVID- $19=14.30+(0.601 *$ Transformational leadership score during COVID- 19$)+(0.422 *$ Transactional leadership score during COVID- 19)

The transformational Leadership style of the supervisor has an impact on employee engagement during both before COVID- 19 and during COVID- 19 situations. The Transactional Leadership style of the supervisor has an impact on employee engagement before COVID- 19 pandemic, but during COVID- 19 does not have a significant impact on employee engagement level.

\section{Findings}

There was a positive relationship between both transformational leadership and transactional leadership on the employee engagement level with work. But, the correlation between the transformational leadership style of the supervisor and the engagement level of the employee before the COVID- 19 pandemic is relatively higher than that during COVID19 and that of the transactional leadership style of the supervisor both before and during COVID- 19. There was a variation in the leadership style and employee engagement before and during COVID- 19 pandemic situation.

The engagement level of employees in the organization has decreased during the COVID- 19 when remote working was prevailing. The leadership style of the supervisors was not found to be statistically different before and during the COVID- 19 pandemic. From the regression analysis of the data, it is found to be that the transformational leadership style of the supervisor has an impact on employee engagement in both before COVID- 19 and during COVID- 19 situations. The Transactional Leadership style of the supervisor has an impact on employee engagement before COVID- 19 pandemic, but during COVID- 19 it did not have a big impact on the employee engagement level.

Usually, transformational leaders are adaptive and understanding. So, even during COVID- 19, they understood the situation and maintained the same style of leadership with their employees. And even though employees and supervisors are working remotely in different workplaces, feedback is given to them whenever required. Because of this, employees feel that there is not much difference in transactional leaders. 


\section{Conclusion}

This study helped to evaluate if there is any change in leadership styles of supervisors before and during COVID- 19 in the IT sector in southern India. Analysis of data showed that the supervisor's leadership style in the IT industry had not changed much during this pandemic. They maintained the same kind of relationship with their subordinates. Employee engagement in the IT Industry had reduced slightly during this pandemic. The causes for this reduction could be factors like lack of inspirational work atmosphere and co-worker motivation. Work-from-Home has therefore impacted employee's will to work.

This research can help Managers to predict and understand the engagement of employees better in times of both remote working and normal working environments. Organizations should start giving more priority to finding effective leaders and developing them for attaining an engaged workforce in the organization. The present study has shown both styles of leadership have an impact on Employee engagement but Transformational leadership before COVID has a higher impact on Employee Engagement. There is a stronger organisational bond for employees if their leaders are transformational.

In conclusion, there is a positive correlation between both the leadership style and employee engagement in all the situations, but transformational leadership's impact on employee engagement before COVID- 19 is higher among all the situations.

\section{References}

[1] Asiedu, EM \& Darko, TO. (2017) Leadership, Employee Engagement and Employee Performance in the Public Sector of Ghana. Journal of Business and Management Sciences, $5(2), 27-34$

[2] Bagyo, Y. (2014, May). Leadership Style In Improving Performance Through Engagement. IOSR Journal of Business and Management (IOSR-JBM), 16(5), 40-49. 10.9790/487X16524049

[3] Bartsch, S., Weber, E., B€uttgen, M., \& Huber, A. (2020, August). Leadership matters in crisis-induced digital transformation: how to lead service employees effectively during the COVID- 19 pandemic. Journal of Service Management. https://doi.org/10.1108/JOSM-052020-0160

[4] Batista-Taran, L. C., Shuck, M. B., Gutierrez, C. C., \&Baralt, S. (2013). The Role of Leadership Style in Employee Engagement. Proceedings of the Eighth Annual College of Education \& GSN Research Conference. https://www.semanticscholar.org/paper/The-Role-ofLeadership-Style-in-Employee-Engagement-Batista-TaranShuck/2693aa8c8720d6a1cf85bedb4bbf860729885131

[5] Bezuidenhout, A., \& Schultz, C. (2013, January). Transformational leadership and employee engagement in the mining industry. Journal of Contemporary Management, 10. https://www.researchgate.net/publication/264500050_Transformational_leadership_and_empl oyee_engagement_in_the_mining_industry

[6] Breevaart, K., Bakker, A., Hetland, J., Demerouti, E., Olsen, O. K., \&Espevik, K. R. (2013, October). Daily transactional and transformational leadership and daily employee engagement. Journal of Occupational and Organizational Psychology, 138-157. https://doi.org/10.1111/joop.12041

[7] Gentry, J. (2012). Understanding Leadership's Role with Employee engagement. https://www.hsdl.org/?view\&did=727366 
[8] Gözükara, İ., \&Şimsek, Ö. F. (2015, December). Role of Leadership in Employees' Work Engagement: Organizational Identification and Job Autonomy. International Journal of Business and Management, 11(1), 72-84. 10.5539/ijbm.v11n1p72

[9] Othman, A. K., Hamzah, M. I., Zakuan, N. M., \& Abas, M. K. (2017, January). The influence of leadership styles on employee engagement: The moderating effect of communication styles. International Journal of Advanced and Applied Sciences. http://www.sciencegate.com/IJAAS.html

[10] Parimalam, M \& Mahadevan, A. (2012). The relationship between Leadership and Employee Engagement: An Employee Course Perspective. Journal of Contemporary Research in Management, 7(4)

[11] Popli, S., \&Razvi, I. A. (2016, June). Drivers of Employee Engagement: The role of leadership style. Global Business Review, 17(4), 965-979. 10.1177/0972150916645701

[12] Ramadevi, V \&Narayanamma, PL. (2016). Impact of Leadership Style on Employee Engagement. Pacific Business Review International, 1(1), 91-98.

[13] Zahid, K., \&Özyapar, A. (2017). Leadership and Employee Engagement in organizations: an analysis on correlation. Master Thesis, IY2542, 2017. 